\title{
Curriculum Development in South African Higher Education Institutions: Key Considerations
}

\author{
${ }^{1}$ Cosmas Maphosa*
}

\author{
2Ndileleni P Mudzielwana
}

2Lufuno Netshifhefhe

${ }^{1}$ University of Fort Hare, South Africa

2University of Venda, South Africa

\section{Doi:10.5901/mjss.2014.v5n7p355}

\section{Abstract}

\begin{abstract}
Core business in a university centres on curriculum. Teaching, learning, assessment and university products all have a bearing on curriculum. In this discussion paper, the researchers engage in theoretical underpinnings of curriculum development in universities in South Africa. The paper is hinged on the realisation that meaningful curriculum development is only possible if academic staff member have a thorough understanding of curriculum, curriculum design principles and processes. Such understanding should be informed by theory. In this paper, the researchers consider curriculum, curriculum orientations and the role of learning outcomes in curriculum development. Important and key considerations in module/course design are discussed and relevant examples given. The issue of alignment, as an important aspect of module/course design, is also explained and exemplified. Conclusions and recommendations are made.
\end{abstract}

Keywords: Curriculum. Curriculum development. Knowledge. Graduate attributes. Competencies. Teaching and learning.

\section{Introduction}

Academics in universities always find themselves tasked to develop curricula by way of designing and developing new courses or modules and reviewing and revising existing ones. Pinar (2004) states that curriculum development is concerned with reviewing, planning, developing, implementing and maintaining curriculum.Reviewing of curriculum involves identifying what is working well, issues and concerns, planning involves the development of curriculum plan) while developing entails development and field test of curriculum programmes. Implementing is putting the curriculum into action and maintaining involves support, sustenance and monitoring of feedback (Pinar, 2004). It is often a daunting task to someone who does not have principles of curriculum design and an understanding of curriculum to engage in meaningful curriculum development exercise. With reference to university lecturers in Kenya and other African countries, Matiru, Mwangi and Schlette (1995: 2) advance the view that:

Currently, only a handful of lecturers have been professionally trained in the art of teaching. The assumption has all along been that the possession of a PhD degree was all that an aspiring lecturer needed in order to be able to teach in a university. The rest one imbibed through osmosis.

Lack of training for lecturers is not restricted to teaching only but also to an important task underpinning teaching such as curriculum planning. Without training and the requisite knowledge and skills, it is assumed that university lecturers will be able to undertake such crucial tasks. Unfortunately, nothing is imbibed by osmosis and one has to be adequately prepared for curriculum development.

On the importance of course and module development, Bunyi (1995:95) states that:

Professionalism in teaching and learning involves more than just planning and teaching a series of lessons. It involves reflecting on and making decisions about one's teaching of the whole course well before it begins.

Curriculum planning, which involves the design and development of programmes and modules or courses, is an endeavour for broad-based thinking on teaching, learning and intended learning outcomes before teaching is done. In 
planning a course or a module, a lecturer has to reflect on how the planned course or module fits into the whole degree programme and its significance thereof. Thijs and van den Akker (2009) note that to be effective, curriculum developers require theoretically underpinned and empirically tested curriculum development principles and methods. To this end, curriculum development is not a layman's work but specialised professional work rooted in deep understanding of what curriculum is.

\section{Curriculum and Curriculum Orientations}

There are many definitions for the concept curriculum. It is essential that academics should have a clear understanding of the concept. Such a clear understanding ensures that academics engage in the curriculum development business with requisite understanding of what they would be doing. Carl (2010) asserts that there is no generally accepted interpretation of the term curriculum and that it is not easy to capture in one description or process. Of particular importance is that how one views curriculum and the context one ascribes to it is often influenced by one's particular curriculum orientation and view of life. Wojtczak (2002) cited in Smithson, 2012:3) defines curriculum as:

\footnotetext{
... an educational plan that spells out which goals and objectives should be achieved, which topics should be covered and which methods are to be used for learning, teaching and evaluation.
}

The above definition of curriculum alluded to the importance of spelling out objectives that a curriculum should be based on. There are, however, other conceptions of the curriculum which do not give primacy to objectives.

On another hand, Coles (2003) cited in Smithson (2012:3) states that:

... curriculum is the sum of all the activities, experiences and learning opportunities for which an institution (such as the society) or a teacher (such as a faculty member) takes responsibility - either deliberately or by default.

In this view curriculum entails all learning experiences planned and organised by the school and also included the unplanned learning experiences.

Tanner and Tanner (2007:12) describe curriculum as:

That reconstruction of knowledge and experience that enables the learner to grow in exercising intelligent control of subsequent knowledge and experience

This quote indicates that it is through curriculum that all activities, ideas and concepts are translated into practice including the process of teaching and learning and assessment. The researchers concur with Barnett (2008) that curriculum is a pedagogic device for helping to fashion human beings of the highest kind.

The word curriculum has many definitions as scholars define it differently according to their various understanding of the concept. Reynolds (2003) cited in Marsh (2009: xvi) uses various metaphors to describe curriculum-lines of light; a river runs through it-and to express images of inspiration, movement, continuity and integration. According to Ornstein and Hunkins (2012:10) curriculum is a 'plan for achieving goals'. This implies that curriculum is an educational plan that spells out which goals and objectives should be achieved, which topics should be covered and which methods are to be used for learning, teaching and evaluation. In planning curriculum, lecturers have to be aware of the specific outcomes to be achieved by students. Coles (2003) argues that a curriculum is more than a list of topics to be covered by an educational programme, for which the more commonly accepted word is a 'syllabus'. A curriculum is first of all a policy statement about a piece of education, and secondly an indication as to the ways in which that policy is to be realised through a programme of action.

The researchers believe that curriculum is the sum of all the activities, experiences context, and learning opportunities for which an institution (such as the society) or a teacher (such as a faculty member) takes responsibility either deliberately or by default. This includes in such a broad concept of curriculum the planned and unplanned experiences. Wiles and Bondi (2011: 2) argues that the most common definition derived from the word Latin root which means race course. Wiles and Bondi (2011: 2) further state that "for many students, the school curriculum is a racecourse to be run, a series of obstacles or hurdle (subjects) to be passed".

In practice, though, a curriculum is more than even this; it is useful to think of it as being much wider. Therefore it means that the institutions must be well prepared when implementing the curriculum. Programmes must have been quality assured by the relevant bodies and that it should be open for scrutiny before they are implemented. Such a view is consistent with Oliva and Gordon's (2013:3) view that "curriculum...is built, planned, designed and evaluated". So the 
researchers believe that until institutions became aware that curriculum should be reviewed and be evaluated by experts before implementation; and that curriculum is the public face of a profession's best educational thinking (Fish, 2003).

When discussing issues related to curriculum one has to bring in the nature of knowledge, what kind of knowledge will the students get from the curriculum; the nature of learning-how are we going to engage the students actively in learning; nature of teaching, how are we going to teach, which strategies will be employed and what kind of activities will be designed to assist students to internalise the knowledge. This is in line with what Maphosa and Mudzielwana (2014) observe that one has to be initiated into the field of teaching in order to understand and appreciate the use of appropriate pedagogical and andragogical approaches; and this include the knowledge of curriculum orientations.

It is critical that academics should be aware how they view curriculum should be influenced by understanding of curriculum orientations. McNeil (2006) stipulates five orientations to curriculum and these are development of cognitive processes, academic rationalism, personal relevance, social adaptation and reconstruction and curriculum as technology. These five orientations dominates teachers' and schools' approaches to curriculum and that teachers should be aware of and how to go about them.

As Carl (2009: xi) states:

This implies that teachers must be involved in curriculum development and that they should have the appropriate skills and knowledge to be able to make a contribution to curriculum development. When one reflects on the role of the teacher as curriculum developer, the whole issue of teacher participation and freedom, as well as democracy in the classroom comes to the fore.

It is therefore important that teachers should have full understanding of what curriculum is and be fully equipped with skills to undertake curriculum development.

\section{The Role of Learning Outcomes in Curriculum Development}

Watson (2002:208) defines a learning outcome as 'being something that students can do now that they could not do previously ... a change in people as a result of a learning experience'. In line with the Tylerian objectives model to curriculum planning, there is always to state the intentions of the curriculum hence the importance of course/module outcomes and learning outcomes. Education and training are concerned with bringing about change in individuals, and setting intended learning outcomes is the most part of curriculum development.

Learning outcomes are important in that the place students at the heart of the learning process by shifting attention from teaching to learning. Robertson (2001) notes that the stating of objectives in curriculum development marks a departure from content-based to student-based curriculum. What is important in a student-based curriculum is the realisation that learning is for students and such learning is measured exhibited behaviours after engagement with curriculum content. Such a curriculum enables students to discover and construct knowledge for themselves (Maher, 2004). Lecturers have to aware of what a student-based curriculum entails in order to plan curricula that are student centred as reflected by appropriate outcomes.

Maher (2004: 48) notes the importance of learning outcomes in showing how students can apply learnt knowledge, skills and values to the world of work by stating that:

Learning outcomes enable universities to express student achievement beyond the narrow boundaries of subject knowledge and to articulate other important skills that are developed during the educational process. Key or transferable skills, relevant professional skills and personal qualities, formerly seen as by-products of the educational process, is now regarded as a core part of studying for a degree.

In the South African higher education context, curriculum is pitched at specific National Qualification Framework level and there certain exit level outcomes at every level. Such exit level outcomes also link student achievement to expectations at that particular level. The Critical Cross Field Outcomes show how students are supposed to exhibit competencies in the outer world. Learning outcomes do not promote the acquisition of knowledge for knowledge's sake but application of knowledge.

An outcomes based curriculum will contain the following aligned components: 


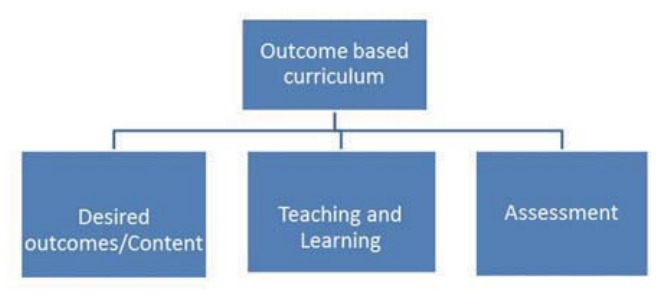

Figure 1: Aligned outcome-based curriculum

The desired outcomes are aligned to the teaching and learning activities and assessment approaches are in line with the desired outcomes. In planning for a curriculum for the training of a foundation phase teacher, an outcome based curriculum will answer questions such as what sort of a foundation phase teacher is sought to be produced, how are demands from key stakeholders reflected, what outcomes and content should be included, what teaching and learning methods would be utilised in training this type of a teacher and how shall the assessment of students be done. Learning outcomes should be written in future tense, identify significant learning requirements, be written in language easily understood by students and should be both achievable and assessable. A learning outcome such as 'to know' is not considered acceptable as it is not achievable and assessable but 'to describe' is both achievable and assessment.

In developing an outcomes-based curriculum academics should have a thorough knowledge of Bloom's Taxonomy of Educational Objectives from where they should draw the relevant verbs to use in stating learning outcomes. The complexity of learning outcomes is consistent with the level of study.

\section{Importance of Making Curriculum Responsive}

According to the Department of Education (1999) higher education institutions and its curriculum plays a critical role in the social, cultural and economic development of the modern societies. The Higher Education Act 101 of 1997 requires that all higher education curriculum must provide education and training to develop the skills and innovation necessary for national development and successful participation in the global economy (Department of Education, 1997).

Curriculum responsiveness has been viewed by many different people to mean so many different things. According to Adam (2009:2) some view curriculum responsiveness as a change and focus in the content, syllabus, or programme of study and even teaching:

University curriculum across the globe is experiencing significant pressure to transform from its 'insular', distant and abstract form to one that is more responsive to the direct needs of the society. This then leads to increased focus on responsiveness resulting in a shift towards mode to knowledge approaches which prioritise curricula that focus on skills, application and problem solving.

Adam (2009) argues that one of the most critical point why curriculum needs to be responsive is the ever changing society, economic and political context in the country. The economy is ever changing and therefore new ideas and knowledge should be available to deal with new challenges. Adam (2009) further observes that while the literature indicates that trends throughout the world tend to privilege particular curriculum discourses informed by global and market pressures at the expense of institutional driving forces, neglecting the role of Agency or local and institutional discourses rooted in the particular histories and culture of institutions (Adam, 2009).

Though the South African Qualification Authority (Nkomo, 2000) argues that in a country like South Africa which has history of deprivation, the nature of the problems that exist in education and training are varied, and it would be simplistic to expect that there is a single solution (Nkomo2000:14).It is still very important that the curriculum should provide benefits to society and the economy through enhancing citizenship, increasing social and economic productivity, providing specifically skilled/professional people and transforming and redressing legacies of previous inequity.

According to Nkomo (2000:16) it is important for a curriculum to be responsive to the community on that it should add value to the quality of learner in terms of enrichment of the person through provision of status, recognition, credentials and licencing, marketability and employability, and opening up of access routes to additional education and training. The researchers fully agree with the Department of Education (1999: 13) which states that "the higher education institutions should have their autonomy with respect to different issues including curriculum." This therefore means that 
each higher education institution within South Africa should ensure that its curriculum is responsive to its own context in line with its vision and mission/mandate.

Ogude, Nel and Oosthuizen (2005: 1) argue that the need for globally equivalent skills raises the debate about curriculum relevance.

Productivity and competitiveness depend on the ability to produce highly skilled and adaptive knowledge workers who can manage and manipulate knowledge and information and adjust to volatile and unpredictable global markets.

According to Ogude, Nel and Oosthuizen (2005) higher education institutions around the world are being called upon to ensure that they become more responsive to the needs of the knowledge economy. Ogude, Nel and Oosthuizen (2005) further note that responsiveness is adaptation to changes in a learning environmental conditions and that responsiveness means meeting society's broad expectations that higher education will adapt to change and contribute to national needs.

According to Moll (2004) curriculum responsiveness promises some positively formulated benchmarks against which we might be able to judge whether our education programmes are meeting the needs of a transforming society. There is an element of continuous improvement implicit in the concept of responsiveness (Ogude, Nel and Oosthuizen, 2010: 2). The National Commission on Higher Education (1996) states that the higher education in South Africa is required to respond to a new set of demands as the new democracy clarifies its growth and development strategy enters the world economy on new terms and begins to tackle political, social and economic reconstruction. These new demands will affect the types of programmes offered, the range of skills graduates will need to develop over their lifetimes, and the nature of knowledge production within higher education and more broadly in society (Department of Education, 1996:81).

The National Commission on Higher Education Report (NCHE) (1996) states that responsiveness should also include an appreciation of the longer - term demands on higher education that flow from a more universal, wider ranging view of its nature and role in human affairs. This means that the new framework will also have to provide enough room for the kind of freedom that will ensure autonomous academic inputs and discretion, so that those longer-term objectives of higher education which the market and the immediate social environment do not and cannot register can be attended to (NCHE, 1996:80)

Ogude, Nel and Oosthuizen (2005)observes curriculum responsiveness as higher education programmes responding adequately to policy requirements and constant to the knowledge and disciplinary practices of higher learning and to the particular developmental and epistemic needs of individual students. They call for a theoretical orientation that can explain how curriculum responsiveness emerges from these levels simultaneously. Curriculum responsiveness can only be achieved in a situation in which disciplinary enquiring and rigour is not compromised, but brought into contact with problems and issues that arise in local context (Moll, 2004).

\section{Calculating Credits and National Hours}

The concept of the credit (also referred to as credit points or credit weighting) has been adopted in South Africa and developed as an indicator of volume of teaching and learning. It is vital to the function of the National Qualifications Framework (NQF) to improve coherence of the higher education system and enable the articulation of qualifications (Academic Development Centre 2009). The Department of Higher Education (2013:8) therefore recognizes credits as:

The measure of the volume of learning required for a qualification and not academic years of study; quantified as the number of notional study hours required for achieving the learning outcomes specified for the qualification. The credit rating of a qualification is independent of the mode of delivery of learning. The attainment of the expected learning outcomes is demonstrated through appropriate assessment.

A credit is usually expressed as a numerical value linked notional hours; whereby one (1) credit is commonly allocated for ten (10) notional hours of learning. However, the definition of notional hours may vary.

The credit system serves as a cornerstone to the administration of higher education institutions internationally, nationally and institutionally. The credit system is increasingly becoming a requirement when one seeks to learn oversees. The credit accumulation and transfer is currently in use in the UK and is currently being implemented in the South African higher education context (Department of Education, 2013:10). As higher education is undertaken by the masses, the credit and notional system therefore provides the ability to manage and compare student's faculty and institutions. This is done by the process of Credit Accumulation and transfer (CAT). Credit accumulation and transfer (CAT) is "the process whereby a student's achievements are recognised and contribute to further learning even if the student does not achieve a qualification. In terms of the CAT scheme, any and all credits for an incomplete qualification 
may be recognised by the same or a different institution as meeting part of the requirements for a different qualification, or may be recognised by a different institution as meeting part of the requirements for the same qualification. Individual mobility between programmes and institutions is thus determined by curriculum requirements and is flexible" (Department of Education, 2013:11).

The concept of credit and notional hours looks at workload from the student's perspective, i.e. not looking at how much content one would like to teach but at how much time it takes the average student to achieve deep learning of the knowledge, skills, attitudes and values that are embodied in a particular module/course.

When one is designing the curriculum it is important to note that the credit ratings on the Higher Education Qualification Framework is just a minimum standard and therefore programmes can require more credit depending on the nature and type of the qualification.

According to the Department of Education (2013:8):

\begin{abstract}
Credit-rating system rates 10 notional study hours as equivalent to one credit. Certificate, Diploma, Bachelor's Degree and Bachelor (Honours) Degree qualification types assume a 30-week full-time academic year. Master's Degree and Doctoral qualification types assume a 45-week full-time academic year. An average full-time equivalent student is expected to study for a 40-hour week, thus requiring a minimum credit-load of 120 credits per academic year for Certificates, Diplomas and Bachelor's Degrees and 180 credits per academic year for Master's Degrees and Doctorates
\end{abstract}

According to the Department of Education (2013) there are six National Qualifications Framework (NQF) levels which range from level 5 (five) to 10 (ten) in the South African education system. These can easily be illustrated in the diagram below which includes the qualification types, levels and minimum credits values:

\begin{tabular}{|l|c|c|}
\hline Qualification types & NQF Level & Minimum total credits \\
\hline Doctoral Degree & 10 & 360 \\
\hline Master's Degree & 9 & 180 \\
\hline Bachelors Honours Degree & 8 & 120 \\
\hline Post Graduate Diploma & 8 & 120 \\
\hline Professional Bachelor's Degree & 8 & 480 \\
\hline Bachelor's Degree & 7 & 360 \\
\hline Advanced Diploma & 7 & 120 \\
\hline Diploma & 6 & 360 \\
\hline Advanced Certificate & 6 & 120 \\
\hline Higher Certificate & 5 & 120 \\
\hline
\end{tabular}

South African Qualification Authority formulation acknowledges that it is impossible to treat all students equally, hence the concept of the "average student". Students vary in innate abilities, background, culture, educational achievements, etc. each student will therefore spend different amount of time on a module but should be encouraged to move at a pace that meets the lecturer's expectations of the amount of work that should be completed by a certain stage of the module. According to Kilfoil (2008) work integrated learning and service learning may increase the amount of time spent on a module/course, but as students are assessed during the sessions the other types of assessment could be reduces to balance the situation (Kilfoil, 2008:2).

\title{
6. Method of Calculating Credit Allocation
}

The calculation of workload in terms of credit is not an automatic process, but one which requires the curriculum developers to engage with the method and intended outcomes of the course. The South African Qualification Authority (SAQA) formula is 10 (ten) notional study hours per credit as alluded before, listing all the activities required including:

Assessment and how long the average student should take to accomplish, the total number of notional study hours should therefore be divided by 10. In case of a full time student in South Africa an average learner should spend 40 learning hours in a 30 weeks academic calendar year programme. Example: formula for a 120 credit qualification will be 1 SAQA Credit X 30 (weeks) X 40 (hours) $=1200$ (notional hours) $=120$ credits (Cele 2010:11)

Notional learning hours are not a precise measure but provide students with an indication of the amount of study and degree of commitment expected. Notional learning time includes among others following: teaching contact time (lectures, seminars, tutorials, laboratory practical's, etc.), time spent on preparation and carrying out formative and summative assessment (written coursework, oral presentation, exams etc.), time spent on private study. 


\section{Key Issues Regarding Module/Course Design}

There are several issues that lecturers should be aware of and take into account in order to engage in effective course or module design.

Course/module description: This is generally the technical component of course or module design in which the title of the course/module is stated, the national qualification levels, qualification level and number of credits.

Course/Module purpose: The lecturer should be able to state explicitly the purpose of the module. When planning a course or module and determining the learning outcomes for that course or module, it is imperative to examine the course's purpose within the context of the university, the college, the school and the department as well as the programme. For example, the purpose of a Citriculture (Citrus Production) offered in a Bachelor of Science Degree in Agriculture Degree with a Horticulture major should be explained. This process will assist school or department in determining the intent of the course as well as how the course fits into the curriculum. This will help identify the essential knowledge, skills and values that should be incorporated into the course and the stated expected learning outcomes for the course. The purpose of shows why the course or module exists, for whom it is designed, how it first into the larger programme and how it will benefit the students, In this regard, the planning of modules and courses should be done by curriculum teams in a school or a department in order to address gaps and overlaps in modules or courses offered in one degree or diploma programme.

Below is an example of a course purpose for anIndependent Study in Public Health course in the School of Health Sciences and Public Health at the St George Washington University:

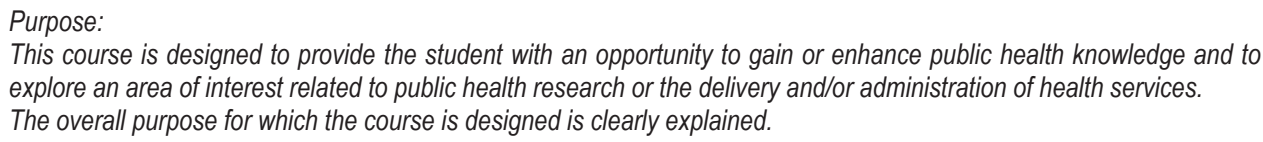

Learning outcomes: As already discussed elsewhere in this paper, learning outcomes are important in designing a module. Watson (2002:208) defines a learning outcome as 'being something those students can do now that they could not do previously ... a change inpeople as a result of a learning experience.' Whetten (2007:344) observes that in stating learning outcomes:

The intended message is that teachers should specify what they expect their students to learn in a course or, more specifically, how they expect their students will be changed by this learning experience and what they should be able to do upon completion.

Learning outcomes show the kind of expectations of changes in students after their engagement with module content and learning activities. There is also need to specify specific learning outcomes regarding each topic in the module. In a Bachelor of Education module on Sociology of education, the module outcome can be stated as follows;

After engaging with module content and learning activities students should be able to:

Analyse the sociological concept of socialisation, its theoretical underpinnings and implications for teaching and learning.

This shows that that in such a module, students shall learn about socialisation and there are certain expectations on what they should do and the verb 'analyse' alludes to a higher order cognitive demand different from mere describing. The stating of learning outcomes should take into account knowledge the lecturer wants the students to have by the end of the course or module, skills that students should master by the end of the course and attitudes that students should demonstrate at the end of the course. Learning outcomes should be realistic, pragmatic and preferably stated in behavioural terms.

Teaching and learning activities: There is need to plan for course or module activities that promote active and engaged learning. Under this section, the lecturer carefully plans the instructional strategies that will be used to help students meet the set learning outcomes and takes consideration to the utilization of out-of-class and in-class time to ensure that students have the opportunity to meet the learning outcomes.

An example of aligning teaching and learning activities to learning outcomes 


\begin{tabular}{|c|c|c|}
\hline $\begin{array}{l}\text { Learning Outcomes } \\
\text { (The sought changes in learners after } \\
\text { engaging with material }\end{array}$ & $\begin{array}{l}\text { Student activities } \\
\text { (What students will do in order to achieve learning } \\
\text { outcomes) }\end{array}$ & $\begin{array}{l}\text { Teacher Activities } \\
\text { (The teacher's facilitation role to } \\
\text { assist students in achieving } \\
\text { outcomes) }\end{array}$ \\
\hline $\begin{array}{l}\text { Course/Module: Principles of human } \\
\text { nutrition } \\
\text { Students will be able to apply nutrition } \\
\text { principles to the needs of children, } \\
\text { adolescents, pregnant and breastfeeding } \\
\text { women. }\end{array}$ & $\begin{array}{l}\text { Individual Reading } \\
\text { Assignment. Students read } \\
\text { Nutrition needs for different categories of people } \\
\text { Small Group Discussion. } \\
\text { Make a presentation on applying nutrition } \\
\text { principles for a given group of people. }\end{array}$ & $\begin{array}{l}\text { Lecture presentation of } \\
\text { Principles of human nutrition } \\
\text { Panel discussion of case } \\
\text { study on nutritional needs, showing } \\
\text { application of principles }\end{array}$ \\
\hline
\end{tabular}

In the above illustration the students and lecturer activities, which account for the way teaching and learning is conducted, have a clear link to the intended learning outcomes. The planned activities show student involvement and engagement in learning and all activities are in pursuit of realising the set outcomes.

Assessments of student learning: In designing a module, the lecturer should also plan for the assessment techniques that will be utilised to ascertain the achievement of set learning outcomes. The purposes of assessment are to improve student learning, monitor student progress, reinforce desired outcomes and behaviours and to provide structure for students. The lecturer should include assessment criteria in module design. Establishing pre-determined standards of performance are the most defensible approach to assessment as these enable students to be clear on what is expected of them after engaging with the learning material. Moon (2002a) states that included in the assessment criteria are the assessment thresholds, showing exactly how students will be scored. An example of as assessment criteria and marking rubric that gives the thresholds is given in Appendix A.

Aligning module to National Qualification Framework (NQF) levels: In the South African higher education context, it is important to ensure that a module is pitched at the accurate NQF level. Each NQF level has level descriptors. Moon (2002b) states that:

The descriptors were developed as a guide to the writing of learning outcomes for modules. This allows modules to be ascribed to a particular higher education level, a process that is essential for functioning within a credit framework. The reference to level descriptors has become essential, too, for the organisation of a modular system - as now exists in most higher education institutions.

In the South African higher education institutions all first year modules should be pitched at HEQSF level 5 , second year modules at level 6 , third and fourth year modules at level 7 and 8 respectively. These levels differ in terms of module complexity. Learning outcomes for a third and fourth year module should be at the upper levels of Bloom's taxonomy of educational objectives (Anderson \& Krathwohl 2001). It is therefore significant that lecturers in SA higher education institution familiarise themselves with the HEQSF levels in order to properly align their modules to these levels.

Aligning module purpose to assessment, stating assessment criteria: Module or course development is one of the most important tasks undertaken by lecturers in university. University lecturers are expected to indicate clearly the module purpose of which must align to assessment and the assessment criteria of which there is need for coherence and cannot develop in isolation, but should respond to the module purpose within a course or programme structure. The module purpose should a coherent rationale statement which explicitly explained the purpose or rationale of and it is important to give consideration to the underlying values and beliefs about the purposes of education. Purpose therefore more about teaching and the management of learning (Moon, 2002a). The focus on the learning; what does the student need to know, do and understand and quality of learning that can be achieved by their students and this will encourage a deep approach to learning.

This implies that the module purpose should do more than add information to students' stock of knowledge but should be seeking to encourage a deep approach to learning and should highlight any major themes, unique aspects. Of importance should also provide information and how it fits into the overall degree structure, including pre and corequisites. In this process assessment criteria should explain how the lecturer will know if the learner has achieved the learning outcomes of the module. The sequence and purpose of assessment obviously needs to support and enhance learning. It should not be seen merely as an add-on to be administered at the end of the programme.

In designing a module assessment practices should be clearly articulated. The relationship between aligning module purpose to assessment, stating assessment criteria significantly influence the effectiveness of student learning.

In showing the importance of constructive alignment module purpose to assessment, stating assessment criteria. 
English and Steffey (2001:25) argue that:

The basic construct for curriculum alignment is to ensure that what is tested is what is taught

The above observation reflects that assessment in higher education is complex and may be impacted by a number of individual and organisational issues; there is need for academics to have knowledge base setting up an aligned system and this requires time and some thought on the part of the academic. A well designed module should inform assessment and assessment criteria.

According to Directorate Quality assurance and development Criteria and Guidelines for Assessment of NQF Registered Unit standards and Qualifications Policy Document (2001) assessment criteria are statements that describe the standard to which learners must perform the actions, roles, knowledge, understanding, skills, values and attitudes stated in the outcomes. There is a clear and transparent expression of requirementsagainst which successful (or unsuccessful) performance is assessed. The assessment criteria should specify the knowledge, understanding, action(s), roles, skills, values and attitudes that a learner has to display in order to provide evidence that outcomes and competence have been achieved, the level of complexity and quality of these and the context of and conditions under which demonstrations should occur. Assessment criteria are therefore statements whereby a lecturer can judge whether the evidence provided by a learner is sufficient to demonstrate competent performance. This implies that it is useful to think of assessment criteria as what one need to see in order to be sure that students can meet the specified outcomes. Assessment criteria may be developed form the assessment tasks the lecturer designed in order to achieve the overall module purpose. It should explain the relationship between how well the student answers the questions set or performs the task set, and the mark and grade given.

Moon (2002a) proposes that there are different types of assessment criteria of which two are distinguished by the different jobs that they do in relation to learning outcomes and that the third is the rest. The two include threshold criterion and grade assessment criterion; and the other forms of assessment that tend to be more generalised in terms of the curriculum they cover.

Black and Wiliam (1998) cited in Carl (2010) state that:

There is a wealth of research evidence that the everyday practice of assessment in classrooms is beset with problems and short-comings.

This implies that assessment should be given serious consideration and the module purpose should link to the assessment and the assessment criteria should be clearly stated. These suggest the need for university teachers becomes imperative in the realisation of designing curriculum.

To this end, Rowntree (2003: 82) reminds us of the importance of meaningful assessment in an education and training system. He maintains that:

If we wish to discover the truth about an educational system, we must look into its assessment procedures. What student qualities and achievements are actively valued and rewarded by the system? How are its purposes and intentions realised? To what extent are the hopes and ideals, aims and objectives professed by the system ever truly perceived, valued and striven for by those who make their way within it? The answers to such questions are to be found in what the system requires students to do in order to survive and prosper.

In this paper we assert that the best preparation for understanding and delivering effective and authentic assessment processes begins with designing module purpose which aligning to assessment, and match with assessment criteria assessment tasks and instruments.

\section{Conclusion}

It is one of the crucial tasks of lecturers to develop modules/courses in their teaching. Unfortunately, lecturers are involved this without any form of training. It has been raised in this paper that in order to effectively engage in module/course design, lecturers need a clear understanding of the concept curriculum as well as curriculum orientations. In the actual design of courses or modules, there are critical issues that should be considered by lecturers. The most important consideration is ensuring alignment of module purpose, content, learning outcomes, teaching and learning activities and assessment strategies. 


\section{Recommendations}

In the light of issues raised in this discussion paper, the following recommendations are made:

a) University lecturers need to understand the concept curriculum for them to be effectively involved in module/course design.

b) Short courses on module/course design in universities are important in ensuring that lecturers have basic skills for this important task.

c) Universities should have curriculum experts who work closely with lecturers in the development of courses/modules. Such experts will offer professional advice whenever lecturers experience challenges.

d) Module/course design should be done by curriculum teams in Faculties and departments to ensure that there is consideration of how modules/courses fit into the whole degree/diploma programmes.

e) Lecturers should always reflect on designed curricula to make them responsive to socio-economic conditions, the discipline and learners, among other issues. Curricula that is not responsive risks being irrelevant.

\section{References}

Academic Development Centre (2009). Understanding and using 'Credits' and 'Notional hours' in course design. Grahamstown: Rhodes University

Adam, F. (2009). Curriculum reform in Higher Education: A Humanities Case Study, PhD Thesis. Johannesburg: University of theWitwatersrand

Anderson, L.W., Krathwohl, D.R.. (Eds.).2001.A taxonomy for learning, teaching, and assessing: A revision of Bloom's taxonomy of educational objectives. San Francisco: Longman.

Barnet, R. (2008).Engaging the curriculum Workshop. Stellenbosch: University of Stellenbosch

Bunyi, G.W. (1995). Course Design.InMatiru B, Mwangi A, Schlette R (Ed) 1995.Teach Your Best - A Handbook for University Lecturers (pp 91 -112). Bonn: German Foundation for International Development (DSE).

Carl, A. E. (2009). Teacher empowerment through curriculum development; theory into practice. Cape Town:Juta and Company Limited.

Cele, N. (2010). The notion of academic standards and integrity and programme design in higher education. CHE, Pretoria.

Coles, C. (2003). 'The development of a curriculum for spinal surgeons', Observations following the Second Spine Course of the Spinal Society of EuropeBarcelona 16th - 19th September 2003

Department of Higher Education (2013). Higher Education Qualifications Sub-Framework. Pretoria: Council of Higher Education.

Department of Education (1996). National Council on Higher Education Report 1996.A Framework for Transformation, Pretoria: CHERC

Department of Education (1997). Higher education Act 101 of 1997, Pretoria: DoE

Department of Education (1999). The White Paper 3: A programme for the transformation of higher education, DoE, Pretoria.

Eisner, E.W. (1970). The educational imagination: On the design and evaluation of school programs. New York: Macmillan.

English, F.W., Steffey, B.E. (2001). Deep curriculum alignment: creating a level playing field for all children on high-stakes tests of educational accountability. Lanham: Rowman \& Littlefield Education.

Fish, D. (2003). 'Education in a community of professional practice: a new approach to curriculum design' in Report of Research for CRUK on a base line of education for Cancer Care, London: CR-UK.

Kilfoil, W. R. (2008). Determining Workload in relation to Credits and Notional Hours. Internal Report, Unisa, pp1 - 5. kilfowr@unisa.ac.za.

Marsh, C. J. (2009).Key concepts for understanding curriculum.(4thed,). New York: Taylor \& Francis.

McNeil, T. (2006). Contemporary Curriculum Development: Theory into practice.New York: MacMillan.

Maher, A. (2004). Learning Outcomes in Higher Education: Implications for Curriculum Design and Student Learning. Journal of Hospitality, Leisure, Sport and Tourism Education3 (2) 46 - 64.

Maphosa, C., Mudzielwana, N.P. (2014). Professionalization of teaching in universities: a compelling case. International Journal of Educational Sciences 6 (1) $65-73$.

Marks, J.R., Stroops, E., King-Stoops, J. (1978). Handbook of educational supervision: a guide for the practitioner. Boston: Allyn and Bacon.

Matiru, B., Mwangi, A., Schlette, R. (Ed) (1995). Teach Your Best - A Handbook for University Lecturers. Bonn: German Foundation for International Development (DSE)

Moll, I. (2004).Curriculum responsiveness: The anatomy of a concept. In: Griesel H, editor. Curriculum responsiveness: Case studies in higher education. Pretoria: South African Universities Vice-Chancellors Association.

Moon, J. (2002a). A Handbook of Programme and Module Development, Kogan Page, London

Moon, J. (2002b). Linking Levels, Learning Outcomes and Assessment Criteria.http://www.ehea.info/Uploads/qualification 104070102Linking Levels plus ass crit-Moon.pdf. Accessed 12 October 2013.

National Council on Higher Education Report (1996). A Framework for Transformation, Pretoria:CHERC

Nkomo, M. (2000). The National Qualifications Framework and Curriculum Development, Pretoria: South African Qualification Authorities

Ogude, N., Nel, H., Oosthuizen, M. (2005).The challenge of curriculum responsiveness in South African higher education. Pretoria: 
Council on Higher Education

Oliva, P. F., Gordon, W.R. (2012). Developing the curriculum.(8th Ed.).Upper Saddle River, NJ: Pearson.

Ornstein, A.C., Hunkins, F.P. (2012). Curriculum: Foundations, Principles and Issues. London: Allyn \& Bacon.

Pinar, W. F. (2004). What is Curriculum Theory?Mahwah, NJ: Lawrence Erlbaum Associates.

Robertson, C. (2001). What's the Outcome? LINK 2, October.LTSN for Hospitality, Leisure, Sportand Tourism.

Rowntree, D. (2003). .Assessing Students: How shall we know them? London: Harper \& Row.

South African Qualification Authority (2000). The National Qualification Framework and Standard Settings Pretoria: SAQA.

Smithson, D. (2012). A curriculum fit for purpose? A discussion paper on the unconscious drive toward hidden curriculums and the effects thereof managing consultant, the inform group.

Tanner, D., Tanner, L. (2007). Curriculum development: Theory into practice. New York: Macmillan.

Thijs, A., van den Akker, J. (Eds.) (2009). Curriculum in development. Enschede, Netherlands: SLO-Netherlands Institute for Curriculum Development. Retrieved from http://www.slo.nl/downloads/2009/curriculum-in-development.pdf/.Accessed 18 October 2013.

Watson, P. (2002). The role and integration of learning outcomes into the educational process.ActiveLearning in Higher Education(3), 205-219.

Whetten, D.A. (2007). Principles Of Effective Course Design: What I Wish I Had Known About Learning-Centered teaching 30 Years Ago. Journal of Management Education, 31 (3): 339-357.

Wiles, J.W. Bondi, J.C. (2011). CurriculumDevelopment: A guide to practice. Upper Saddle River,NJ:PearsonEd.

Wojtczak, A. (2002).Glossary of Medical Education Terms, http://www.iime.org/glossary.htm, Accessed 8 November 2013

Appendix A: Example of an Aligned Module

Course Title: Bachelor of Education (FET/TEF)

Module Title: Sociology of Education

Level : NQF Level 6 - Second Year

Credits: 120

Module Purpose

To equip students with knowledge of the relationship between education and society through the study of sociological theories and their influence on educational practice.

Module Outcome

By the end of the module students should be able to;

a) Analyse the sociological concept of socialisation, its theoretical underpinnings and implications for teaching and learning. Assessment Criteria

a) Socialisation is defined in a scholarly way by referring to authoritative sources and the functions of different socialisation agents are adequately examined

b) Relevant theories underpinning socialisation are clearly referred to.

c) Practical classroom examples are identified and explained adequately to support implications of socialisation to teaching and learning.

Topic: Socialisation and Education

Learning outcomes: By the end of the topic students should be able to;

a) identify different socialisation agents and explain how they socialise children

b) describe agents that promote wrong socialisation of children and discuss measures that could be taken to minimise wrong socialisation

c) analyse the school socialisation function

Teaching and Learning Activities

Group Research and Presentation

- $\quad$ Students are work in groups of five

- $\quad$ Each group works on a given socialisation agent e.g. family, peer group, media, church, the school, religion

- The group consults library for texts, journal articles and internet sources for 2 weeks.

- $\quad$ Each group establishes a scholarly definition of socialisation, examines the function of the given agent in socialisation and draw implications for teaching and learning

- $\quad$ Group presentation are done in class with each group presenting for 20 minutes and responding to questions

Discussion groups

Debate

Assessment Procedures

Formative Assessment

Task 1:In groups of five choose one agent of socialisation and show how it socialises the child

Task 2: The class is divided into two. They prepare for a debate. One group supports modern technology in children's life these days while the other opposes and looks at its dangers 
Summative Assessment

Written Assignment

Essay Question

- Using relevant sociological theories on socialisation examine the functions of at least five socialisation agents in socialising the child. Assess the implication of the socialisation of children on teaching and learning at FET or TEF level.

Implementation of Assessment Task

- $\quad$ Lecturer shows how the essay should be written and developed.

- Class brainstorms on ideas to be included in the essay.

- $\quad$ Students to search for own information to answer the questions

- $\quad$ Students take three weeks to work on the assignment - a major assessment task.

- A final draft of 8 pages (double spacing - font 12) is submitted in person or online on agreed date.

- Work is assessed within two weeks and feedback is given to students

Assessment Rubric

\begin{tabular}{|c|c|c|c|}
\hline Criteria & Above Average & Average & Below Average \\
\hline $\begin{array}{l}\text { Function of socialisation } \\
\text { agents }\end{array}$ & $\begin{array}{l}\text { Five socialisation agents are } \\
\text { clearly identified and fully } \\
\text { explained with functions } \\
\text { critically examined by } \\
\text { referring to relevant } \\
\text { sociological theories. Clear } \\
\text { and real classroom } \\
\text { examples are given to } \\
\text { assess implication on } \\
\text { teaching and learning }\end{array}$ & $\begin{array}{l}\text { At least three socialisation } \\
\text { agents are identified and } \\
\text { reasonably explained. Functions } \\
\text { are fairly examined and some } \\
\text { reference is made to theories. } \\
\text { Some examples are given }\end{array}$ & $\begin{array}{l}\text { Only one agent is identified / } \\
\text { No agent is identifies. } \\
\text { Explanation of identifies } \\
\text { agents is scanty or there is no } \\
\text { explanation at all. No } \\
\text { reference to theories and no } \\
\text { implications to teaching and } \\
\text { learning drawn. }\end{array}$ \\
\hline $\begin{array}{l}\text { Idea Development and } \\
\text { interpretation of readings }\end{array}$ & $\begin{array}{l}\text { Ideas are well developed in } \\
\text { paragraphs. The student } \\
\text { brings citations into } \\
\text { discussion, interprets what is } \\
\text { read and maintains a clear } \\
\text { author's voice. }\end{array}$ & $\begin{array}{l}\text { Ideas are superficially } \\
\text { developed, often mixed or } \\
\text { incomplete. } \\
\text { inconsistencies in interpretation } \\
\text { of readings with author's voice } \\
\text { scantily maintained. }\end{array}$ & $\begin{array}{l}\text { There are serious challenges } \\
\text { in noting and developing } \\
\text { ideas and paragraphs are not } \\
\text { well developed. Ideas are } \\
\text { presented without interpreting } \\
\text { readings. }\end{array}$ \\
\hline Academic Writing Style & $\begin{array}{l}\text { Referencing is done } \\
\text { excellently and consistently } \\
\text { in both in-text referencing } \\
\text { sand the compilation of } \\
\text { reference list. }\end{array}$ & $\begin{array}{l}\text { Referencing fairly well done with } \\
\text { some noted } \\
\text { deficiencies/inadequacies in } \\
\text { both in-text referencing and } \\
\text { compilation of reference list }\end{array}$ & $\begin{array}{l}\text { Serious challenges with } \\
\text { referencing. Inaccurate/poor } \\
\text { or no in-text referencing. } \\
\text { Inaccurate/poor or no } \\
\text { reference list. }\end{array}$ \\
\hline $\begin{array}{l}\text { General Presentation and } \\
\text { Neatness }\end{array}$ & $\begin{array}{l}\text { Well typed, edited and proof- } \\
\text { read. Well-presented and } \\
\text { virtually error-free }\end{array}$ & $\begin{array}{l}\text { Fairly well presented, with few } \\
\text { errors of omission. }\end{array}$ & $\begin{array}{l}\text { Work is badly presented and } \\
\text { full of errors, showing lack of } \\
\text { editing and proof reading. }\end{array}$ \\
\hline
\end{tabular}

